\title{
The Importance of Information and
}

\section{Communication Technologies (ICT) during the COVID-19-Pandemic in Case of Kosovo (Analytical Approach of Students Perspective)}

\author{
Aferdita Qekaj-Thaqi' ${ }^{1}$, Ledri Thaqi \\ ${ }^{1}$ Faculty of Public Safety, Kosovo Academy for Public Safety, Pristina, Kosovo \\ ${ }^{2}$ Faculty of Data Science, University of Zurich, Zürich, Switzerland \\ Email: aferdita06@gmail.com, thaqiledri52@gmail.com
}

How to cite this paper: Qekaj-Thaqi, A. and Thaqi, L. (2021) The Importance of Information and Communication Technologies (ICT) during the COVID-19-Pandemic in Case of Kosovo (Analytical Approach of Students Perspective). Open Access Library Journal, 8: e6996.

https://doi.org/10.4236/oalib.1106996

Received: April 27, 2021

Accepted: July 13, 2021

Published: July 16, 2021

Copyright $\odot 2021$ by author(s) and Open Access Library Inc.

This work is licensed under the Creative Commons Attribution International License (CC BY 4.0).

http://creativecommons.org/licenses/by/4.0/

\section{Abstract}

The COVID-19 pandemic is an unprecedented and unimaginable occurrence for people around the world. The COVID-19 pandemic makes people feel fear and panic about the risks that could cause the virus SARS-Cov2, but likewise also for social welfare, standard of living, workplace, salary and other aspects of people's social life. A major event is precisely the closure of schools and the transition to online learning which undoubtedly highlighted the importance of the ICT sector. A global concern is also the efficiency of online teaching and learning methods for pupils and students. In this regard, we have significant differences in the economic development of countries. Low-income countries are also expected to face barriers to online learning imposed by the pandemic as a result of insufficient development of the sector of Information and Communication Technology (ICT). The main aim of this paper is to shed light on the importance of ICT sector via students/pupils perception of the effectiveness of online learning methods during the COVID-19 pandemic in case of Kosovo. The method used to achieve the aim of this paper is an online questionnaire that is distributed using social media. The samples in the analysis are pupils and students from the private and public schools/universities in Kosovo. IBM SPSS Statistics is used for data analyzing including Descriptive Statistics, Frequencies, Pearson Correlation and Chi-Square Test of Independence. The paper comes to conclusion that private schools/universities in comparison with the public ones in case of Kosovo are in advantage, they are well prepared regarding ICT and during online teaching have used more effective methods including Google Platforms such us: Google forms, Google meet, etc. The paper comes with further recommendations for schools/universities 
in particular and in general for the Government exactly Government Spending in ICT Sector in case of Kosovo.

\section{Subject Areas}

Information and Communication Technology and Online Learning

\section{Keywords}

ICT, Students/Pupils, Online Learning, Private/Public Schools/Universities, COVID-19 Pandemic

\section{Introduction}

The COVID 19 Pandemic is a recent topic debated and addressed by numerous researchers in various spheres of social life. For a very short time, a deadly virus annihilated even the world power countries making them all equal to fight this challenge. Even Kosovo is facing many challenges towards facing and fighting the spread of COVID-19. In December 2019, a viral outbreak of pneumonia of unknown origin occurred in Wuhan, China. On 9 January 2020, the World Health Organization (WHO) officially announced the discovery of a novel coronavirus: SARS-Cov2. This new virus is the pathogen responsible for this infectious respiratory disease called COVID-19 (Coronavirus Disease). (Marinoni, Land, \& Jensen, 2020) [1] [2]. The whole world was in deep panic when the World Health Organization declared this deadly virus as a pandemic worldwide in March 2020 specifically on March 11,2020. The pandemic caused many surprises in every aspect of life. This pandemic significantly changed people's lifestyles by imposing new measures and for most people unacceptable and not easily enforceable. The globally COVID-19 Pandemic caused fear first and foremost for people's health, their lives, and then numerous financial problems for families, corporations and governments. This deepened the panic of the society by imposing insecurity for any kind of social action taken by them. There are a number of studies that have been dedicated to the impact of the COVID-19 Pandemic in every sphere of life including economy, social, health, education and other aspects. The focus of this study is the analysis of the transformation of traditional learning or in school learning to distance learning that highlights the importance of ICT sector in the case of Kosovo from the perspective of pupils/students who study in public and private schools/universities. Among other things, a comparison will be made between private and public schools/universities preparation and adjustment to the online learning that was imposed by the COVID-19 Pandemic.

In principle, the purpose of any government has been to protect the health of citizens and then all measures have been adapted to prevent the spread of the virus SARS-Cov2. In the framework of these measures, were also the immediate measures to stop physical attendance in schools and to switch the teaching 
process from traditional to online trying to use different online platforms and communication tools. The closing of schools that was imposed by the COVID-19 Pandemic and the shift to online learning has undoubtedly required a mutual commitment between the government, educational institutions, teachers and parents, thus imposing the use of ICT.

This mutual communication has been a challenge for all participants, especially for pupils and parents. Online learning caused great confusion among pupils in primary schools, mainly small age groups of children have faced great difficulties during the interruption of traditional learning and switching to distance learning due to the fact that they find it difficult to understand isolation, social distance, digital learning platforms and so on. In this prism we can also emphasize the deep gap created between children living in urban and rural areas, excellent pupils and those with average or poor performance, but also pupils who have parents with academic experience and those who do not have this experience. We can conclude that less challenging the online learning has resulted for students for the sake of their age and continuous use of technology and digital devices.

Online learning has also been challenging for teachers due to the fact that they have necessarily to be trained in new ways of creating online and interactive learning. To what extent it has been possible to conduct such training in the case of Kosovo or elsewhere in developing countries is a topic itself that requires additional research. A quite important issue that this study raises for discussion is how the used forms of online learning from teachers were expected by the pupils/parents and the students themselves and how they perceive the success of the online learning form that they participated in. The situation is more complicated for parents especially for working parents to follow their children during online learning and also maintain working hours. The transition from traditional to online learning in the case of Kosovo as a developing country has certainly resulted in many challenges for the government, educational institutions, students and parents.

Educational institutions suddenly have to adapt to the new way of learning which differs from the traditional approach where students meet at school and have direct communication to the distance learning. Educational institutions by decision of the Government to protect the welfare of pupils and students from the spread of the COVID-19, were obliged to close and continue with online learning. The logistics of implementing online learning are determined by the schools themselves, meaning there was no strict guideline on which online platform should have been used by educational institutions. With a variety of online form's where some teachers have used social networks, some Edmo, some have implemented online learning with Zoom or through Google Meet, these tools help to get acquainted with the perception of how children and students appropriately evaluate the form of online learning that they have followed. Thus, there was no single uniform strategy from the government but in most cases, especially for children, different approaches such as course scheduled public television 
broadcasting and through photos on social networks were used, excluding the cases when students attended online lessons on various platforms of direct connection via Google platforms or ZOOM.

In this regard, some questions are raised such as how much governments spend on ICT; how much they have supported the growth and training of IT staff to help use digital equipment and platforms for online learning; how much teachers have been trained and how students have been educated about online learning etc. Distance learning is the biggest challenge for parents due to the fact that working parents find it difficult to follow the performance of the child. Thus, it is obvious that we will have differences in performance between exemplary students, average ones and those with poorer academic performance. Taking into consideration participation levels, we are aware that distance learning has impacted more the students with average and poor level of performance compared to the exemplary ones. No matter the tool that is used for online learning and regardless of the digital devices that are used, this difference will be even more pronounced when students return to attend the schools physically.

For this and many other reasons, Kosovo as a developing country is facing many challenges in this regard. Current school closures have added to the time that most students already spend at home during the summer months without explicit face-to-face instruction from teachers. Meanwhile, teachers are scrambling to adapt content for an online platform and parents are juggling work responsibilities (if not joblessness) with caring for and educating their own children. Students themselves are faced with isolation, anxiety about a deadly virus, and uncertainty about the future. In so many ways, the current situation is unprecedented for most of the people (Soland, et al., 2020) [3] [4].

\section{Review of Related Literature}

The COVID 19 Pandemic caused a series of changes in people's lives all around the world. Every single change results in great consequences for the states economies, the health and education system, citizens' welfare, generally caused radical changes in people's lives. Radical changes followed as a result of the deadly virus that alarmed the world. Thus every government tried following the guidelines of the world health organization (WHO) took immediate measures to prevent the spread of the virus and to keep it under control. The measures that were generally taken in almost every country were the closure of borders, the restriction of the movement of citizens, wearing of masks, the preservation of personal and collective hygiene and social distancing. However, in certain states and countries, the quarantine of entire cities was imposed, a wide range of economic activities were closed, suspending every sphere of life in order to prevent the spread of the virus. The immediate decision to close schools and universities aroused the greatest panic among the citizens.

School closures due to COVID-19 have left over a billion students out of physical attendance in schools. Governments are pursuing a variety of approaches to 
mitigate school closures. At the same time, all countries are undergoing the largest economic contractions of our lifetime, reducing public budgets and household incomes (Azevedo, Hasan, Goldemberg, Iqbal, \& Geven, 2020) [1] [5]. The closure of schools posed a series of dilemmas over the utilization of different methods for implementing online learning and their effectiveness.

An extraordinary discussion has taken place on the platforms that can be used for online learning and obviously here we have conjecture on how effective they can be taking into account the economic development of countries in the world. Another issue is the impact of the use of digital platforms on pupil and student behavior: 1) the educational institution's general or legal duty of care for the safeguarding and mental health of those who may be isolated from peer contact, particularly those with special educational needs; 2 ) how those using online services are protected from cyber-attacks-which may also seek to hack institutional systems; 3) how online assessment can be secured against academic misconduct while protecting the ECHR right to privacy of individuals'. (Farrington, 2020) [6]. In this regard, each country has taken measures based on economic and technological capacities, always based on suggestions from the World Health Organization and the Ministry of Health of the respective countries. The statewide poll, conducted by Global Strategy Group for The Education Trust-West, finds that $81 \%$ of respondents rate school leaders' general handling of the closures as "excellent" or "good." But it also reveals that the crisis is exacerbating longstanding education equity challenges, including inequitable access to technology, academic support, and resources for students of color and students from lower-income communities (Costa, 2020) [5] [7]. Concretely, every crisis, be it economic, political, etc., deepens the inequality between the rich and the poor. In this context, the COVID-19 Pandemic has significantly deepened the inequality among students from several perspectives, the first has to do with the possibility of access to online learning due to technology, the second has to do with the capacity of students to gain knowledge through online learning and the third students with lower intelligence will always have difficulty gaining solid knowledge through online platforms. These three segments significantly deepen the inequality caused during online learning. Also the IAU Global Survey Reportindicate between others that the risk for COVID-19 to increase inequality among HEI's around the world is due to access to technology, as well as for the financial dependence on student recruitment (Marinoni, Land, \& Jensen, 2020) [1] [2].

Regarding the ILO Sectorial Brief Report, teachers and schools have been creative in adopting a variety of technology-based strategies as alternatives to the traditional classroom, providing lessons through videoconferencing and online learning platforms and sharing learning materials and worksheets through schoolbased intranets and messaging platforms, in some countries radio programs and national television are being used to broadcast school lessons and educational materials, particularly in under-resourced areas that may be lacking in technological infrastructure (International Labor Organization (ILO), 2020) [8]. Also a 
big dilemma is how many working students would like to attend online lessons. A paradox in this regard may lie in the fact that distance learning allows students to access from any place with any digital platform when only internet access is enough and on the other hand different researchers see access to learning as an obstacle if students are engaged with work.

Information from ILO projects to eliminate child labor indicates that school children who had been in or were at risk of child labor are less likely to access distance learning. In such disadvantaged communities, the quality of distance learning, usually low-tech or notech, may be poor.

The risk that school systems will experience high rates of drop out, during the pandemic and in its aftermath, and that child labor will increase is clear (International Labor Organization (ILO), 2020) [8]. However, no matter how developed a country is in the economic sense or the ICT sector that is seen as necessary for online learning in times of pandemic, school dropout is a huge loss. The COVID-19 pandemic has caused the largest disruption of education in history, having already had a near universal impact on learners and teachers around the world, from pre-primary to secondary schools, technical and vocational education and training (TVET) institutions, universities, adult learning, and skills development establishments (United Nations, 2020) [2] [9]. About the crisis that is causing the COVID-19 Pandemic is stated also at the report of UNDP among others that this systemic crisis hits a world dealing with unresolved tensions: between people and technology, between people and the planet and between the haves and the have-nots-all of which are shaping a new generation of inequalities (UNDP, 2020) [10] [11].

The transition from traditional to online learning has necessitated the involvement of parents, the pupil/student himself/herself, internet access and the need for digital devices. Which means without the support of these players the success of online learning is indisputable. This has significantly increased inequality among pupils/students. While some believe that the unplanned and rapid move to online learning - with no training, insufficient bandwidth, and little preparation-will result in a poor user experience that is in conducive to sustained growth, others believe that a new hybrid model of education will emerge, with significant benefits (World Economic Forum, 2020) [4] [12]. The global lockdown of education institutions is going to cause major (and likely unequal) interruption in students' learning; disruptions in internal assessments; and the cancellation of public assessments for qualifications or their replacement by an inferior alternative (Burgess \& Sievertsen, 2020) [3] [11].

School dropouts are considered a major shortcoming in gaining knowledge for students. According to (Giorgio, Federico, Patricia, Zbigniew, \& Jacopo, 2020) [7] [9]. First, there is evidence showing that quarantined students tend to spend less time learning compared to when schools are open; second, many students confined at home due to COVID-19 may feel stressed and anxious, and this may negatively affect their ability to concentrate on schoolwork and third, physical 
school closing and the lack of in-person contact may make students less externally motivated to engage in learning activities.

One of the few benefits from this current situation that is being caused by the COVID-19 Pandemic is the possibility that through the opportunities that the ICT sector offers, the educational institutions moved from traditional to online learning quickly in accordance with the imposed conditions and thus enabled online learning for all students. Regarding ICT sector in Kosovo according to the Presentation by PwC North Macedonia, the curriculum of the education system (tertiary education) does not a meet the needs and requirements of IT companies, which negatively affects the competitiveness of local IT companies, also specialized formal and training-focused education programs are necessary to increase the skill set of local IT graduates and professionals (PricewaterhouseCoopers $(\mathrm{PwC}), 2020, \mathrm{p} .73)$. The report also states that the Internet users as a percentage of total population in case of Kosovo is $88 \%$; total number of active mobile internet users is 1.49 Million and Mobile Internet users as a percentage of total population is 78\% (PricewaterhouseCoopers (PwC), 2020, p. 80) [10] [12]. This shows that the majority of the population has access to internet and uses it for a wide range of needs. We can conclude that students in Kosovo do not encounter problems in accessing the internet thus it does not affect the online learning in time of COVID-19.

\section{Research Methodology}

The COVID-19 pandemic forced every country in the world to close a large number of activities among others alienated the most unexpected form of learning for all school closing. The main purpose and focus of this study is to identify how the COVID-19 pandemic affected online learning and how students perceive the success of the forms used by higher education institutions to realize distance learning. In order to achieve this goal, an extensive international and national literature and an adequate research method have been used to achieve the goal. The data that is used in this research is primary data. As a research method to gather the primary data the online questionnaire was used.

The online questionnaire has concretely made it possible for this scientific research to respect the confidentiality of the respondents and of course the preservation of social distance. The questionnaire was distributed on social networks dedicated to pupils and students. The total number of respondents is 500 between them pupils and students attending private or public schools/universities. After the data gathering the questionnaire is coded and prepared for IBM SPSS Statistics that is used for data analyzing including Descriptive Statistics, Frequencies, Pearson Correlation and Chi-Square Test of Independence. The results are interpreted through tables.

\section{Data Analysis and Results}

In this section we will go through interpretation of the results including descrip- 
tive statistics, frequencies, Pearson Correlation and Chi-Square Test of Independence.

Table 1 present descriptive statistics of the main variables including residence of the respondents, age of the respondents and if they are a student in primary school, secondary school, bachelor or master students. From the total number of the respondents (500) we have a standard deviation for the gender 0.477 , for the residence of the respondent the standard deviation is 0.286 , for the age is 1.31 and for the respondents education level is 0.5 . More descriptive statistics can be found in Appendix.

As we noted that the data used in this research is primary data that we gathered using online questionnaire we will present the respective findings. From all the 500 respondents, 326 of the respondents were female and 174 of the respondents were male. Regarding the question about where the respondents live, what we can notice is that the majority of the respondents live in the city (455 of them) and only 45 of them live in the rural areas.

Concerning the respondents age, in the age 6 - 14 we have in total 64 respondents, aged 15 - 19 we have in total 122 respondents, 20 - 25 we have 124 respondents, 26 - 35 we have 93 respondents and aged 36 - 45 we have in total 97 respondents. Regarding the level of the respondent's education we can conclude that a large number of the respondents possess a master degree, especially 185 of the respondents are master students. 147 are pupils in primary school, 97 are bachelor students and only 71 of the total number of the respondents are pupils at secondary school. 300 of the respondents study in public schools/universities and 200 of them in private schools/universities. Regarding the question of regularity of attendance during online learning by pupils/students. 402 respondents answered that they attend online learning regularly, 69 of them answer that sometimes attend the lectures online and only 29 answer that they do not attend the lectures online. From the total number of the respondents 294 answered that they were notified in advance about the methods of online learning, 137 of the respondents answered that they do not have any information related the online learning methods and 69 of them have no comment about this issue. A large

Table 1. Descriptive statistics of the main variables.

\begin{tabular}{cccccc}
\hline \multicolumn{5}{c}{ Descriptive Statistics } \\
& $\mathrm{N}$ & Minimum & Maximum & Mean & Std. Deviation \\
\hline Gender & 500 & 1 & 2 & 1.35 & 0.477 \\
Your Residence & 500 & 1 & 2 & 1.09 & 0.286 \\
$\begin{array}{c}\text { Your age (if completed by the } \\
\text { parent, please specify the }\end{array}$ & 500 & 1 & 5 & 3.07 & 1.310 \\
age of the child) & & & & & \\
You are: & 500 & 1 & 2 & 1.49 & 0.500 \\
Valid N (listwise) & 500 & & & &
\end{tabular}

Source: author's calculations, IBM SPSS. 
percentage of the respondents answered no-exactly $47 \%$ of the respondents did not accept any guidance at all for the online learning form, $44 \%$ of them answer that they have had the guidance about the online learning forms and only $9 \%$ answered that they do not have any guide at all for online learning forms.

Regarding the digital devices that the respondents have used to attend the online learning, we have a large number of the respondents exactly 347 of the respondents which have used a laptop device, 68 of the respondents used smart phones, 40 of the respondents have used a desktop computer, 23 have used tablet and 22 have chosen the option other. Regarding the question if the respondents have had access to internet that was inalienable for attendance of online learning in period of COVID-19 pandemic, 332 of the respondents have had always internet access, 116 of the respondents sometimes did not have internet access and only 52 of the respondents answer that in very rare cases they do not have internet access. Thus we can conclude that internet access is not a problem for students to attend online lessons regularly in case of analysis.

Related the forms that pupils/students have attended the online learning during COVID-19 Pandemic, 232 of the respondents choose the option ZOOM or Skype, 199 of the respondent's answer that they have attended the online learning via Google platforms including Google classroom, Google meet or Google forms etc. And 69 of the respondents answer that they attend the online learning via Viber or social media including Facebook and Instagram.

For the appropriateness of the online learning method for pupils/students, 185 of the respondents answered neutral, 132 of them found the method very convenient, 53 of the respondents found the method to somewhat convenient and only 30 of the respondents answered not at all convenient. The results also show that the pupils/students achievement of knowledge during online learning versus they would achieved normally via traditional learning is not the same. In assertion "The Covid-19 Pandemic caused concern for you by imposing distance learning and you did not achieve the required level of knowledge versus you would have achieved normally" 160 of the respondents chose totally agree, 146 were neutral, 109 agreed, 47 did not agree at all and 38 did not agree.

Almost 284 of the respondents totally agree with the assertion: "You prefer more traditional learning versus online learning", 38 of the respondents agreed, 63 were neutral, 53 did not agree and 32 of the respondents did not agree at all. Regarding the assertion: "Do you think that public educational institutions in Kosovo have adapted online learning strategies based on international standards", when 231 of the respondents were neutral, 170 of the respondents answered no and only 99 answered yes. From the total number of the respondents 215 answered that private educational institutions in case of Kosovo are in advantage with online learning over public ones, 155 answered no and 130 had no comment. The data about the respondent's suggestions to Ministry of Education of Kosovo regarding the forms of learning during COVID-19 pandemic shows that from the total number of the respondents, 254 suggested combined learning 
methods that means partly in schools/universities and partly online, 193 suggested pupils/students to begin with traditional learning (at schools/universities) and only 53 of the respondents suggested to continue with distance learning.

In regards to test the relationship between conceptual variables in this research we have also used the Pearson Correlation, also known as a Pearson Coefficient that measures the relationship between two variables. The condition values for Pearson Correlation Coefficient are between -1 to +1 which means if the coefficient is -1 the relationship between two variables is negative that means negatively correlated and if the coefficient is +1 that means the variables are in perfect positive correlation with each other. In this research due to the main aim of the paper and question raised for the analysis are defined the conceptual variables including:

Var1: The age of the respondents, specifically the question: Your age (if completed by the parent, please specify the age of the child);

Var2: The education level of the respondents;

Var3: The status of the school/university (private or public) when respondents attend their study;

Var4: The achievement of the knowledge for pupils/students via online learning versus traditional learning;

Var5: The pupils/students preference about traditional learning versus online learning;

Var6: The appropriateness of the online learning method for pupils/students.

After the discussion of the conceptual variables we will interpret now the relationship between them based on the Pearson Coefficient (Table 2).

As we can see from the Pearson Correlation matrix the variable "The age of the respondents exactly the question: Your age (if completed by the parent, please specify the age of the child)" is positively correlated but in weak relationship with the variable, the education level of the respondents at the coefficient level 0.003 . Variable one is negatively correlated with variable three "The status of the school/university (private or public) when respondents attend their study"

Table 2. Pearson correlation.

\begin{tabular}{|c|c|c|c|c|c|c|c|}
\hline \multicolumn{8}{|c|}{ Correlations } \\
\hline & & Var 1 & Var 2 & Var 3: & Var 4 & Var 5 & Var 6 \\
\hline Var 1 & Pearson Cor. & 1 & & & & & \\
\hline Var 2 & Pearson Cor. & 0.003 & 1 & & . & . & \\
\hline Var 3 & Pearson Cor. & $-0.210^{\star *}$ & -0.029 & 1 & & & \\
\hline Var 4 & Pearson Cor. & 0.024 & 0.004 & $0.135^{\star *}$ & 1 & & \\
\hline Var 5 & Pearson Cor. & 0.076 & 0.004 & 0.080 & $0.196^{\star *}$ & 1 & \\
\hline Var 6 & Pearson Cor. & -0.013 & -0.001 & -0.044 & $-0.409^{* *}$ & -0.089 & 1 \\
\hline
\end{tabular}

${ }^{* *}$ Correlation is significant at the 0.01 level (2-tailed); Source: author's calculations, IBM SPSS. 
as a result of the Pearson Coefficient (0.210). Variable one is in positive but weak relationship with the variable "The achievement of the knowledge for pupils/ students via online learning versus traditional learning" at the level of the coefficient 0.024 and also with the variable "The pupils/students preference about traditional learning versus online learning" 0.076 .

Variable one is negatively correlated with the variable "The appropriateness of the online learning method for pupils/students" at the level of the coefficient (0.013), thus we can conclude that the age of the respondents is negatively correlated with the variables "The status of the school/university (private or public) when respondents attend their study" and "The appropriateness of the online learning method for pupils/students" and in positive relationship with the other conceptual variables. "The education level of the respondent" as second conceptual variable is negatively correlated with the variable "The status of the school/university (private or public) when respondents attend their study" as a result of the Pearson Coefficient (0.029) and also with the variable "The appropriateness of the online learning method for pupils/students" (0.001) but in is in positive weak relationship with the variables "The achievement of the knowledge for pupils/students via online learning versus traditional learning" and "The pupils/students preference about traditional learning versus online learning" with the Pearson Coefficient 0.004 .

The variable "The status of the school/university (private or public) when respondents attend their study" is in positive relationship with the variables "The achievement of the knowledge for pupils/students via online learning versus traditional learning" with the Pearson Coefficient 0.135 and "The pupils/students preference about traditional learning versus online learning" at the level of Pearson Correlation 0.080 and in negative relationship with the variable "The appropriateness of the online learning method for pupils/students" (0.044).

Variable four "The achievement of the knowledge for pupils/students via online learning versus traditional learning" is positively correlated with the variable "The pupils/students preference about traditional learning versus online learning" with the Pearson Coefficient 0.196 and is negatively correlated with the variable "The appropriateness of the online learning method for pupils/students" (0.409).

The variable "The pupils/students preference about traditional learning versus online learning" is negatively correlated with "The variable the appropriateness of the online learning method for pupils/students" with the Pearson Correlation (0.089).

In Table 3 we present the cross tabulation between two variables: 1) the age of the respondents exactly the question: Your age (if completed by the parent, please specify the age of the child) and 2) the variable or the question: Do you think that private educational institutions in Kosovo are in advantage in online learning over public ones. Related the age of the respondents in a sample of 500, 24 of the respondents aged $6-14$ respond to the question: Do you think that private educational institutions in Kosovo are in advantage in online learning over public ones-yes, 24 no and 16 neutral in total 64 . 
Respondents aged 15 - 19, 68 of them responded yes, 8 of them responded no and 46 had no comment in total 122. The respondents aged 20 - 25 in total are 122 from whom 54 responded yes, 32 responded no and 38 responded with no comment. The respondents aged 26 - 65 which are in total 93, from whom 40 responded yes, 38 responded no and 15 had no comment. From the respondents aged 36 - 45 in total we have 97 respondents from them 29 responded yes, 53 no and 15 responded with no comment.

In Table 4 the Chi-Square tests are presented, that means the test of independence that measure if the relationship between two variables is statistically significant. Asymptotic Significance (2-sided) is 0.000 below the alpha level normality exactly less than 0.005 and this means that the association between the two variables in our case the opinion of the respondents regarding the advantage of private schools/universities versus public ones with the age of the respondents is statistically significant.

Table 3. Cross tabulation table.

The age of the respondents exactly the question: Your age (if completed by the parent, please specify the age of the child) ${ }^{*}$ Do you think that private educational institutions in Kosovo are in advantage in online learning over public ones?

\begin{tabular}{|c|c|c|c|c|c|}
\hline \multicolumn{6}{|c|}{ Count } \\
\hline & & \multicolumn{3}{|c|}{$\begin{array}{l}\text { Do you think that private educational } \\
\text { institutions in Kosovo are in advantage } \\
\text { in online learning over public ones }\end{array}$} & \multirow[t]{2}{*}{ Total } \\
\hline & & Yes & No & No comment & \\
\hline \multirow{5}{*}{$\begin{array}{l}\text { The age of the respondents } \\
\text { exactly the question: Your } \\
\text { age (if completed by the } \\
\text { parent, please specify the } \\
\text { age of the child) }\end{array}$} & $6-14$ & 24 & 24 & 16 & 64 \\
\hline & $15-19$ & 68 & 8 & 46 & 122 \\
\hline & $20-25$ & 54 & 32 & 38 & 124 \\
\hline & $26-35$ & 40 & 38 & 15 & 93 \\
\hline & $36-45$ & 29 & 53 & 15 & 97 \\
\hline Total & & 215 & 155 & 130 & 500 \\
\hline
\end{tabular}

Source: author's calculations, IBM SPSS.

Table 4. Chi-Square tests of independence.

\begin{tabular}{cccc}
\hline & \multicolumn{2}{c}{ Chi-Square Tests } \\
\hline & Value & Df & Asymptotic Significance (2-sided) \\
\hline Pearson Chi-Square & $69.910^{\mathrm{a}}$ & 8 & 0.000 \\
Likelihood Ratio & 78.161 & 8 & 0.000 \\
Linear-by-Linear Association & 2.101 & 1 & 0.147 \\
N of Valid Cases & 500 & & \\
\hline
\end{tabular}

${ }^{\mathrm{a}} 0$ cells $(0.0 \%)$ have expected count less than 5 . The minimum expected count is 16.64 . Source: author's calculations, IBM SPSS. 


\section{Conclusions and Recommendations}

The COVID-19 Pandemic is a global issue that affected a lot of people in many countries around the world. Kosovo as a developing country also dealt with the ways how to stop the spread of the virus SARS-Cov2. This virus is causing a lot of trouble to the whole people in the world. The Kosovo's citizens dealt with the fear of their health, wages and social wellbeing. A crucial debate and a very debated issue is also the education system and the path from traditional learning to distance learning that was also the main aim of this paper. Using the online questionnaire for primary data gathering, in a total sample of 500 respondents (between them pupils in primary and secondary school and bachelor and master students in private/public school/universities) the paper concludes that in Kosovo there is no problem for internet access thus the online learning can be effectively used by educational institutions and pupils/students.

Almost all of the respondents between others stated that online learning is not the solution for the long term future because it is not considered the most adequate method, the respondents see as a solution a combined learning method partly in school as traditionally and partly in distance. A huge number of the respondents are in dilemma about the online learning effectiveness in pupils in primary schools especially aged $6-10$ because of their maturity. Online learning seems to be quite acceptable for students because they do not have problems using different digital devices to attend the online learning. The online methods that were used by educational institutions were well accepted by the respondents instead of theirs age or their level of education. Regarding the data analysis and the review of related literature the paper comes with further recommendations including:

- Teachers need to be well prepared and trained for online learning to raise the virtual communication between groups. To achieve this, the educational institutions should spend more budget for their staff training especially more commitments and professional training.

- Pupils/Students should have more guidance for online learning methods. They should have detailed guidelines on how to use the online platforms.

- Governments should support educational institutions both private and public in the fight against COVID-19 pandemic with precise rules and regulations.

- Government should take into account the digital equipment needed for online learning and tend to provide digital equipment (laptop) for every family that has children in schools/universities and is a category of low-income families.

- Regular monitoring of the Ministry of Education on public and private institutions related the effectiveness of the methods used for online learning as due to the respondents many of the teachers have not even once organized online meetings with students. As long as teachers are paid for the full rate, then the commitment must be in line with this rate.

At least if online learning is to be continued as a result to prevent the spread of the virus, everything possible must be done to equip all pupils/students with 
the necessary tools for learning, otherwise great injustice will be done to those children who do not have the necessary means to attend online learning. Finally, a strong recommendation is to equip schools/universities with digital tools and subsequently support the pupils/students to lower the gap between families that cannot and can afford digital equipment.

\section{Conflicts of Interest}

The authors declare no conflicts of interest.

\section{References}

[1] Marinoni, G., Land, H.V. and Jensen, T. (2020) The Impact of COVID-19 on Higher Education around the World. International Association of Universities, France.

[2] United Nations (2020) Policy Brief: Education during COVID-19 and beyond. https://www.un.org/development/desa/dspd/wp-content/uploads/sites/22/2020/08/s g_policy_brief_covid-19_and_education_august_2020.pdf

[3] Soland, J., Kuhfeld, M., Tarasawa, B., Johson, A., Ruzek, E. and Liu, J. (2020) The Impact of COVID-19 on Student Achievement and What It May Mean for Educators. Brookings Institution, Washington.

[4] World Economic Forum (2020) The COVID-19 Pandemic Has Changed Education Forever. This Is How. The World Economic Forum COVID Action Platform. https://openknowledge.worldbank.org/handle/10986/33945

[5] Azevedo, J.P., Hasan, A., Goldemberg, D., Iqbal, S.A. and Geven, K. (2020) Simulating the Potential Impacts of the COVID-19 School Closures on Schooling and Learning Outcomes: A Set of Global Estimates. The World Bank Group. https://www.worldbank.org/en/topic/education/publication/simulating-potential-i mpacts-of-covid-19-school-closures-learning-outcomes-a-set-of-global-estimates

[6] Farrington, D. (2020) The Consequences of COVID-19 on the Education System: The Legal Perspective. Council of Europe.

https://www.coe.int/en/web/education/article-the-consequences-of-covid-19-on-the -education-system-the-legal-perspective

[7] Costa, K. (2020) California Parents Very Concerned About Children Falling Behind During School Closures. Education Trust-West, Califronia.

[8] International Labor Organization (ILO) (2020) COVID-19 and the Education Sector. ILO.

https://www.ilo.org/sector/Resources/publications/WCMS_742025/lang--en/index. $\underline{\mathrm{htm}}$

[9] Giorgio, D.P., Federico, B., Patricia, D.M., Zbigniew, K. and Jacopo, M. (2020) He Likely Impact of COVID-19 on Education: Reflections Based on the Existing Literature and Recent International Datasets.

https://ec.europa.eu/jrc/en/publication/likely-impact-covid-19-education-reflection s-based-existing-literature-and-recent-international

[10] UNDP (2020) COVID-19 and Human Developmen: tAssessing the Crisis, Envisioning the Recovery. United Nations Development Programme 1 UN Plaza, New York.

[11] Burgess, S. and Sievertsen, H.H. (2020) Schools, Skills, and Learning: The Impact of COVID-19 on Education. VOX EU.

https://voxeu.org/article/impact-covid-19-education

[12] Pricewaterhouse Coopers (PwC) (2020) ICT Sector Study North Macedonia, Albania, Kosovo. PwC North Macedonia, North Macedonia. 


\section{Appendix}

\begin{tabular}{|c|c|c|c|c|c|}
\hline \multicolumn{6}{|c|}{ Descriptive Statistics } \\
\hline & $\mathrm{N}$ & Minimum & Maximum & Mean & Std. Deviation \\
\hline Gender & 500 & 1 & 2 & 1.35 & 0.477 \\
\hline Your Residence & 500 & 1 & 2 & 1.09 & 0.286 \\
\hline $\begin{array}{l}\text { Your age (if completed by the parent, please } \\
\text { specify the age of the child) }\end{array}$ & 500 & 1 & 5 & 3.07 & 1.310 \\
\hline You are: & 500 & 1 & 4 & 2.64 & 1.250 \\
\hline The school/university where you study is: & 500 & 1 & 2 & 1.60 & 0.490 \\
\hline $\begin{array}{c}\text { The Covid-19 Pandemic forced all schools to distance } \\
\text { learning (by Government decision). Have you } \\
\text { attended online tutorials regularly? }\end{array}$ & 500 & 1 & 3 & 1.33 & 0.707 \\
\hline $\begin{array}{l}\text { Before you start with online learning, you have been } \\
\text { acquainted with the teaching realization manner? }\end{array}$ & 500 & 1 & 4 & 1.69 & 1.022 \\
\hline $\begin{array}{l}\text { Before you started learning online did you have a } \\
\text { detailed guide to online learning forms? }\end{array}$ & 500 & 1 & 5 & 1.83 & 1.096 \\
\hline $\begin{array}{c}\text { YOU have attended online lessons } \\
\text { using digital devices: }\end{array}$ & 500 & 1 & 5 & 1.73 & 1.216 \\
\hline You have always had access to the Internet? & 500 & 1 & 3 & 1.44 & 0.675 \\
\hline In what form have you attended online lessons? & 500 & 1 & 3 & 1.67 & 0.705 \\
\hline $\begin{array}{l}\text { Has the form of online learning you followed been } \\
\text { acceptable and appropriate for you personally? }\end{array}$ & 500 & 1 & 5 & 3.50 & 1.163 \\
\hline $\begin{array}{l}\text { The Covid-19 Pandemic caused concern for you by } \\
\text { im1sing distance learning and you did not achieve } \\
\text { the required level of knowledge versus you would } \\
\text { have achieved in the normal period? }\end{array}$ & 500 & 1 & 5 & 3.59 & 1.265 \\
\hline $\begin{array}{l}\text { You prefer more traditional teaching } \\
\text { versus online learning }\end{array}$ & 470 & 1 & 5 & 4.04 & 1.343 \\
\hline $\begin{array}{c}\text { Do you think that public educational institutions in } \\
\text { Kosovo have adapted online learning strategies based } \\
\text { on international standards? }\end{array}$ & 500 & 1 & 6 & 3.65 & 2.208 \\
\hline $\begin{array}{l}\text { Do you think that le educational institutions in } \\
\text { Kosovo have an advantage in online } \\
\text { learning over public ones? }\end{array}$ & 500 & 1 & 4 & 2.09 & 1.210 \\
\hline $\begin{array}{l}\text { Do you think that the Government of Kosovo should } \\
\text { spend more budget for the development of the } \\
\text { Information and Communication Technology sector }\end{array}$ & 500 & 1 & 4 & 1.27 & 0.801 \\
\hline $\begin{array}{l}\text { Which of the following forms of learning did you persona } \\
\text { suggest to the Ministry of Education in Kosovo to } \\
\text { implement in this year of KOVID } 19 \text { Pandemic? }\end{array}$ & 500 & 1 & 3 & 1.88 & 0.939 \\
\hline Valid N (listwise) & 470 & & & & \\
\hline
\end{tabular}

